\section{Gene}

Volume 379,1 September 2006, Pages 40-50

http://dx.doi.org/10.1016/j.gene.2006.04.011

(C) 2006 Elsevier
Archimer, archive institutionnelle de l'Ifremer http://www.ifremer.fr/docelec/

\title{
A transcriptomic approach of salinity response in the euryhaline teleost, Dicentrarchus labrax
}

\author{
I. Boutet ${ }^{\underline{a}}$, C.L. Long $\mathrm{Ky}^{\mathrm{b}}$ and F. Bonhomme $\mathrm{e}^{\mathrm{a}}$
}

\author{
aUMR CNRS-IFREMER 5171 Génome, Populations, Interactions, Adaptation, Station Méditerranéenne de \\ l'Environnement Littoral, 1 Quai de la Daurade, 34200 Sète, France \\ ${ }^{\mathrm{b}}$ Station IFREMER de Palavas-les-Flots, Chemin de Maguelone, 34250 Palavas-les-Flots, France \\ Corresponding author : boutetisabelle@yahoo.fr
}

\begin{abstract}
:
Euryhaline teleosts possess the capacity to osmoregulate under various environmental conditions (freshwater to hypersaline water). This physiological capacity is generally monitored using enzyme activity assays ( $\mathrm{Na}+/ \mathrm{K}+-\mathrm{ATPase} . .$.$) , hormones quantification (prolactine, growth hormone) or their$ mRNAs expression. To date, few studies addressed the genetic correlates of adaptation to varying salinity at a molecular level in such fish. In the sea bass Dicentrarchus labrax, genetic differentiation was observed at specific allozyme loci between lagoon- and open-sea populations. In the present study, we investigated transcriptomic response of D. labrax to salt- and freshwater acclimation in two organs involved in osmoregulation, gill and intestine. By using suppression subtractive hybridisation, we characterised 586 partial cDNA sequences encoding proteins potentially involved in the metabolism of sea bass acclimated to salt- or freshwater under experimental conditions. Using these results, we first characterised complete genomic sequence of a carbonic anhydrase and then analysed mRNA expression of genes potentially involved in osmoregulation mechanisms ( $\mathrm{Na}+/ \mathrm{K}+-\mathrm{ATPase}$, carbonic anhydrase, angiotensin-converting enzyme and claudin-3), cell-cycle regulation (secretagogin) and immune system (nephrosin) in gill and intestine of wild fish from open sea and lagoons. Our analyses indicate a strong tissue- and environmental-dependant expression pattern for all the genes studied. A transcriptomic approach such as described in the present paper provides thus a first description of genes involved in metabolic or structural functions important for coping with environmental salinity variations in a euryhaline fish like the common sea bass D. labrax. It should be supplemented by proteomics to check the direct involvement of the gene products at the protein level, and by polymorphism analyses if one is to understand population or individual fluctuations in acclimation to salinity variation.
\end{abstract}

Keywords: Sea bass; mRNA expression; Osmoregulation; Carbonic anhydrase; Suppression subtractive hybridisation 


\section{Introduction}

Terrestrial and aquatic organisms have to control and maintain the osmotic presure of their cells by regulating fluxes of ions and water through the cell membrane, often with some metabolic cost. The ability of an aquatic organism to tolerate wide variation of salinity without compromising life processes is called euryhalinity (in opposition to stenohalinity). Marine teleost fishes tend to lose water through osmosis and to gain ions (essentially $\mathrm{Na}^{+}$and $\mathrm{Cl}^{-}$) through diffusion (ingestion of seawater, excretion of small volume of urine and active excretion of salt through the gill), whereas the reverse mechanism occurs in freshwater fishes (excretion of relatively dilute urine, active uptake of salt across the gill and possibly some ingestion of salt in the food) (Alderdice, 1988).

Numerous studies have investigated the effects of salinity changes in teleosts at a physiological level (osmoregulation enzyme activity and hormones quantification, urine volume measurement...) and in term of specific mRNA expression variations $\left(\mathrm{Na}^{+} / \mathrm{H}^{+}\left(\mathrm{NH}_{4}^{+}\right)\right.$exchanger, $\mathrm{Na}^{+} / \mathrm{K}^{+} / 2 \mathrm{Cl}^{-}$cotransporter) (Hirose et al., 2003). The activity of ion-transporters is particularly well studied in seawater challenged fishes. A seawater transfer of salmons, Onchorhynchus kisutch or Salmo salar, and brown trout, Salmo trutta, resulted in a gradual adjustment of $\mathrm{Na}^{+} / \mathrm{K}^{+}$-ATPase and $\mathrm{Na}^{+} / \mathrm{K}^{+} / 2 \mathrm{Cl}^{-}$cotransporter expression in gill epithelial cells (Tipsmark et al., 2002). It was observed that some $\mathrm{Na}^{+} / \mathrm{K}^{+}$-ATPase subunits mRNA levels increased with environmental salinity, while some others decreased, in tilapia Oreochromis mossambicus and rainbow trout Onchorhynchus mykiss tissues (Richards et al., 2003). Besides, the responses of fishes to freshwater challenges are particularly studied through the quantification and the expression of the hormone prolactin that is involved in adaptation to fresh water. Prolactin plays a major role in osmoregulation in freshwater fishes by regulating water and salt fluxes through the gills and kidney (change in membrane permeability and development of chloride cells) (Forsyth and Wallis, 2002). As was observed for several hormones, prolactin becomes efficient after its binding to the prolactin receptor that activates intra-cellular signalling pathways such as tyrosine kinase, MAPK (mitogenactivated protein kinase), Src kinase and the activation of ion channels (Freeman et al, 2000). In laboratory conditions, tilapia showed a strong increase of prolactin concentration in response to a salinity decrease (Weber et al., 2004). In the tilapia O. mossambicus exposed to various salinities (from fresh water to seawater), Streelman and Kocher (2002) demonstrated a relationship between (1) the length of different microsatellite alleles in the promoter region of the prolactin gene, (2) the gene expression, and (3) the ability of fishes to survive under different salinity conditions. This work provided one of the first in vivo evidence that differences in microsatellite length among individuals may indeed affect gene expression and that variation in expression has concomitant physiological consequences.

The common (or European) sea bass Dicentrarchus labrax L. (Teleost, Perciformes, Moronidea) is a marine teleost of great economical importance in the Mediterranean area able to survive under various salinity conditions (Jensen et al., 1998). The sea bass acquires tolerance to fluctuating salinity very early during development, already present at hatching, and increasing throughout development (Varsamos et al., 2001, Hirose et al., 2003). Physiologically, this capacity is characterised by the presence of mitochondria-rich cells in the gill epithelium, named chloride cells, and capable of regulating ion content during salinity changes (Varsamos et al., 2002). D. labrax is able to colonise coastal lagoons and estuaries as well as the open sea, but mating and spawning occur only at sea (Barnabé, 1980). Previous works demonstrated a significant genetic differenciation between lagoon and marine sea bass (Lemaire et al., 2000) and before and after freshwater acclimation under experimental conditions (Allegrucci et al., 1995). To date, the response to salinity changes in teleosts has primarily been examined at a physiological level. Recently, Nebel et al. (2005) have dissected some of the physiological correlates of individual variation in the capacity of seabass to adapt to freshwater.

In the present study, we investigated the response of the sea bass $D$. labrax to freshwater and seawater acclimation under experimental conditions by a transcriptomic approach. We first determined the differentially regulated genes after a six-month period in saltwater and in fresh water using a suppression subtractive hybridisation (SSH) method. We then investigated the mRNA expression of $\mathrm{Na}^{+} / \mathrm{K}^{+}$-ATPase, angiotensin-converting enzyme (ACE), secretagogin, nephrosin and claudin-3, according to their role in various cellular metabolism, by semi-quantitative RT-PCR in sea bass from open sea (near Sète, French Mediterranean coast) and a nearby coastal lagoon (Ingril, Mediterranean). We also characterised gene sequence and mRNA expression of carbonic anhydrase in experimentally 
acclimatised to fresh- and saltwater sea bass and in sea- and lagoon-caught individuals. We discuss the validity of these different genes as markers of adaptation of sea bass to various salinity conditions.

\section{Materials and methods}

\subsection{Sea bass conditioning and collection}

Two groups of D. labrax juveniles (both male and female seabass weighing $20 \pm 1.5 \mathrm{~g}$ ), progeny originated from a complete factorial sheme $3 \times 3$ obtained by artificial breeding at IFREMER (Palavasles-Flots, Hérault, France) were reared in recirculating $20^{\circ} \mathrm{C}$ salt water, under natural photoperiod. Transfer to fresh water were carried out according to the protocol described by Nebel et al. (2005). After a six-month period (i.e. complete acclimation), surviving fishes in fresh water $(n=10)$ and seawater $(n=10)$ were collected, dissected, and intestine and gill tissues were sampled and stored at $-80^{\circ} \mathrm{C}$ until used. During the experiment, the fish were fed daily on adapted commercial pellets (Le Gouesnant, Lamballe, France). For all experiments, the principles of laboratory animal care were followed. The fish were anesthetised in a solution of phenoxy-2-ethanol $(150 \mu \mathrm{g} / \mathrm{l})$ prior to any manipulation.

Adult wild sea bass were collected in December 2004 from the Mediterranean Sea $\left(35 \%\right.$; $\approx 11^{\circ} \mathrm{C}$; collected about 3km offshore; $n=5$; Hérault, France) and from the Ingril lagoon (28.5\%o at collection time; $\approx 5^{\circ} \mathrm{C} ; n=5$; Hérault, France). If salinity is roughly constant in the sea across the year, data have shown that salinity may vary from 3.5\% up to 41\% in the Ingril lagoon which is very shallow (2004 survey; Syndicat Intercommunal des Etangs Littoraux, pers. comm.). All individuals were dissected and intestine and gill tissues were collected in tubes and stored at $-80^{\circ} \mathrm{C}$ until RNA extraction.

\subsection{Suppression subtractive hybridisation}

Total RNA was extracted from the intestine and gills tissues of saltwater and freshwater acclimated fishes $(n=10)$ using Trizol (Invitrogen, Carlsbad, CA, USA) according to the manufacturer's instructions. Poly(A+) mRNA was isolated from total RNA using the Nucleotrap ${ }^{\circledR}$ mRNA midi purification kit (BD Biosciences, Palo Alto, CA, USA) according to the manufacturer's instructions. Two subtracted libraries per salinity condition were generated. Two libraries contained partial transcripts of genes up-regulated in intestine and gills of saltwater-acclimated fishes, while the two other libraries contained those that were up-regulated in intestine and gills of freshwater-acclimated fishes. The libraries were obtained by subtracting out the cDNA common to both the saltwater acclimated fishes and freshwater acclimated fishes, leaving the differentially expressed partial transcripts from the saltwater and freshwater fishes to be amplified. First and second strand cDNA synthesis, RsaI endonuclease enzyme digestion, adapter ligation, hybridisation, and PCR amplification were performed as described in the PCR-select cDNA subtraction manual (BD Biosciences). The differentially expressed PCR products were cloned into pGEM-T vector (Promega, Madison, WI, USA). Ligation mixtures were transformed into DH5 $\alpha$ Escherichia coli competent cells. Three hundred white colonies per library were isolated, grown in LuriaBertani medium (containing 100 $\mathrm{g} / \mathrm{l}$ ampicilline) and sequenced (MWG-Biotech AG, Ebersberg, Germany). All sequences were subjected to a homology search through the BLASTX program (www.ncbi.nlm.nih.gov/BLAST).

\subsection{Cloning and sequencing of carbonic anhydrase cDNA, gene and proximal promoter region}

Total RNA was extracted from the gill tissue of one experimentally saltwater acclimated sea bass using Trizol (Invitrogen, Carlsbad, CA, USA) according to the manufacturer's instructions. The procedures for the generation of carbonic anhydrase cDNA 5' and 3' untranslated regions (UTR) were carried out according to the commercial 5'/3' rapid amplification of cDNA ends protocol (5'/3' RACE Kit, Roche, Mannheim, Germany) using specific antisense (5'-TGT AAC TCC ATG GGA TAG CGC TTT CCA TC-3') and sense (5'-AGC TGG AAC ACT TTG ACC TCC TAC CTG GC-3') primers for the 5' and the 3' UTR, respectively. The 3' UTR was amplified as follows: $200 \mathrm{ng}$ of reverse transcription product was submitted to amplification using one cycle at $94^{\circ} \mathrm{C}$ for $2 \mathrm{~min}, 58^{\circ} \mathrm{C}$ for $2 \mathrm{~min}, 72^{\circ} \mathrm{C}$ for $2 \mathrm{~min}$ 30 , then 35 cycles at $94^{\circ} \mathrm{C}$ for $15 \mathrm{~s}, 58^{\circ} \mathrm{C}$ for $30 \mathrm{~s}, 72^{\circ} \mathrm{C}$ for 2 min and a final step at $72^{\circ} \mathrm{C}$ for 10 min with 
$2 \mathrm{mM} \mathrm{MgCl}_{2}$ and 10 pmol each of PCR anchor primer (5'-GAC CAC GCG TAT CGA TGT CGA C-3') and specific primer. Amplification of the 5' UTR was carried out according to the following procedure: denaturation at $94^{\circ} \mathrm{C}$ for $2 \mathrm{~min}$, then 10 cycles at $94^{\circ} \mathrm{C}$ for $15 \mathrm{~s}, 58^{\circ} \mathrm{C}$ for $30 \mathrm{~s}, 72^{\circ} \mathrm{C}$ for 1 min, then 30 cycles at $94^{\circ} \mathrm{C}$ for $15 \mathrm{~s}, 58^{\circ} \mathrm{C}$ for $30 \mathrm{~s}, 72^{\circ} \mathrm{C}$ for 1 min with an increase of $20 \mathrm{~s}$ per cycle for the elongation time, and a final step at $72^{\circ} \mathrm{C}$ for 15 min with $2 \mathrm{mM} \mathrm{MgCl}_{2}$ and $10 \mathrm{pmol}$ each of oligo dT anchor primer (5'-CGC TCT AGA ACT AGT GGA TCT $(16)^{-3}$ ') and specific primer. The resulting cDNA fragments corresponding to the 5' and 3' UTRs were cloned into pGEM-T vector (Promega), transformed in DH5 $\alpha$ E. coli competent cells and sequenced (MWG-Biotech AG).

Total genomic DNA was isolated from sea bass muscle using phenol/chloroform/isoamyl alcohol (25:24:1). The resulting preparation was amplified with primers (5'-GGA GGT ACA GGT GCG TCA AAG ATG AAC TGG-3' and 5'-CCT GTA AAC TTA GTG CAA GTG CAT TCC TGC C-3') using UptiTherm DNA polymerase (Interchim). Two hundred ng of DNA were submitted to amplification using denaturation at $94^{\circ} \mathrm{C}$ for $5 \mathrm{~min}$, then 15 cycles at $94^{\circ} \mathrm{C}$ for $30 \mathrm{~s}, 58^{\circ} \mathrm{C}$ for $30 \mathrm{~s}, 72^{\circ} \mathrm{C}$ for 3 min, then 15 cycles at $94^{\circ} \mathrm{C}$ for $30 \mathrm{~s}, 58^{\circ} \mathrm{C}$ for $30 \mathrm{~s}, 72^{\circ} \mathrm{C}$ for 3 min with an increase of $10 \mathrm{~s}$ per cycle for the elongation time, and a final step at $72^{\circ} \mathrm{C}$ for 30 min with $2 \mathrm{mM} \mathrm{MgCl}_{2}$, and $10 \mathrm{pmol}$ of each primer. The resulting product was cloned into pGEM-T vector (Promega), transformed in E. coli DH5 $\alpha$ competent cells and finally sequenced (MWG-Biotech AG).

The characterisation of the proximal promoter region was conducted by using a modified GenomeWalker protocol as follows. First, 10 $\mathrm{gg}$ of genomic DNA was partially digested by the PvuII restriction enzyme in a $100 \mu \mathrm{l}$-final reaction volume for $2 \mathrm{~h}$ at $37^{\circ} \mathrm{C}$. A $20 \mu \mathrm{l}$ volume was removed every 30 min, stopped with $1 \mu \mathrm{l}$ of EDTA/glycogen mix and stored on ice until use. The digested DNA was then purified with $150 \mu \mathrm{l}$ of phenol-chloroform-isoamylic alcohol (25:24:1), precipitated with 4M ammonium acetate and ethanol 100, and dried. The DNA pellet was suspended in $10 \mu \mathrm{l}$ of water. Digested DNA was then ligated overnight at $16^{\circ} \mathrm{C}$ with two different adapters (5'-CGA GCG GCC GCC CGG GCA GCA G3' and 5'-CTG CTG CCC GGG CGG CCG CTC G-3'). The reaction was stopped by incubating the mix $5 \mathrm{~min}$ at $72^{\circ} \mathrm{C}$, and diluted in $100 \mu \mathrm{l}$ of dilution buffer $(20 \mathrm{mM} \mathrm{HEPES}-\mathrm{HCl} \mathrm{pH}$ 8.3, $50 \mathrm{mM} \mathrm{NaCl}, 0.2 \mathrm{mM}$ EDTA pH 8). PCR amplification was performed by using Advantage ${ }^{\circledR}$ cDNA PCR kit (BD Biosciences) as follow: one cycle at $75^{\circ} \mathrm{C}$ for $5 \mathrm{~min}$, one cycle at $94^{\circ} \mathrm{C}$ for $1 \mathrm{~min}, 30$ cycles at $94^{\circ} \mathrm{C}$ for $30 \mathrm{~s}, 57^{\circ} \mathrm{C}$ for $40 \mathrm{~s}$ and $72^{\circ} \mathrm{C}$ for $4 \mathrm{~min}$ with PCR primer (5'-CGA GCG GCC GCC CGG GCA GCA G-3') and a reverse carbonic anhydrase primer (5'-TGT AAC TCC ATG GGA TAG CGC TTT CCA TC-3'). A nested PCR was performed on the first PCR product (1:10 diluted) as follow: 30 cycles at $94^{\circ} \mathrm{C}$ for $30 \mathrm{~s}$, $59^{\circ} \mathrm{C}$ for $40 \mathrm{~s}$ and $72^{\circ} \mathrm{C}$ for $3 \mathrm{~min}$ and a final extension of $15 \mathrm{~min}$ at $72^{\circ} \mathrm{C}$ with PCR primer (10pmol) and a reverse carbonic anhydrase primer (10pmol) (5'-CCA GTT CAT CTT TGA CGC ACC TGT ACC TCC-3'). PCR product was separated on 1.5\% agarose gel using 0.5X TBE-buffer and visualised on UV after Ethidium Bromide staining. A 1000 bp fragment was obtained and the band was excised from gel and extracted using the QIAEX II purification kit (Qiagen, Hilden, Germany) according to manufacturer's instructions. The purified product was then ligated into pGEM-T vector (Promega), transformed in E. coli DH5 $\alpha$ competent cells and the alkaline lysis minipreparation was finally sequenced (MWG-Biotech AG).

\subsection{Gene expression analysis by using semi-quantitative RT-PCR in wild sea- and lagoon-caught bass}

Total RNA was extracted using Trizol from experimental individuals (acclimated to saltwater and fresh water, $n=5$ each, carbonic anhydrase expression analysis only), open sea and Ingril lagoon individuals ( $n=5$ each, environmental characteristics in section 2.1). Ten $\mu$ g of RNA were submitted to reverse transcription using an oligo dT primer and M-MLV reverse transcriptase (Promega, Madison, WI, USA). To perform semi-quantitative RT-PCR, the total amount of isolated total RNA was quantified by UV-spectroscopy at $260 \mathrm{~nm}$. Amplification of $\mathrm{Na}^{+} / \mathrm{K}^{+}$-ATPase, claudin-3, ACE, nephrosin and secretagogin were performed in a $25 \mu \mathrm{l}$-final volume containing $2 \mathrm{mM} \mathrm{MgCl}$ and $10 \mathrm{pmol}$ of each primers (Table 1) as follows: one cycle at $94^{\circ} \mathrm{C}$ for $2 \mathrm{~min}, 55^{\circ} \mathrm{C}$ for $2 \mathrm{~min}$ and $72^{\circ} \mathrm{C}$ for $1 \mathrm{~min} 30 \mathrm{~s}$; between 25 and 40 amplification cycles (according to the gene, see table 1 ) at $94^{\circ} \mathrm{C}$ for $30 \mathrm{~s}, 55^{\circ} \mathrm{C}$ for $30 \mathrm{~s}$ and $72^{\circ} \mathrm{C}$ for $1 \mathrm{~min} 20$ followed by a final $7 \mathrm{~min}$ extension at $72^{\circ} \mathrm{C}$. The optimal number of PCR cycle was determined for each gene studied as the number of PCR cycle necessary to obtain a PCR product in the exponential phase. A PCR amplification control (28S ribosomal DNA) was used for all experiments and was amplified as described above with primers described in table 1. PCR product was separated on $1.5 \%$ 
agarose gel using 0.5X TBE-buffer and photographed after ethidium bromide staining. Quantification of band intensity was made using Gene Profiler Software v. 4.03 (Scanalytics, Inc.). Statistical analysis (non-parametric test Kruskall-Wallis) was performed with Statistica software v. 6.0.

\section{Results}

\subsection{Identification of salinity-regulated genes}

SSH libraries were generated from intestine and gills of freshwater- or seawater-acclimated D. labrax. The search for homology using the BLASTX program revealed 586 different sequences and amongst them 450 (about 77\%) corresponded to unidentified genes (unknown function or no hits). Four tables list the sequences obtained from the SSH libraries: freshwater up-regulated genes in intestine (Table 2), seawater up-regulated genes in intestine (Table 3), freshwater up-regulated genes in gills (Table 4) and seawater up-regulated genes in gills (Table 5). These results indicate that saltwater and freshwater acclimation involved at least eight major cellular physiological functions during the experiment: osmoregulation, protein regulation (including protein synthesis, transport and degradation), nucleic acid regulation (including transcription and metabolism of nucleic acid components), cell cycle regulation, respiratory chain and energetic metabolism, lipid metabolism, cell communication (including immune system, cell protection and membrane receptors), and cytoskeleton.

\subsection{Carbonic anhydrase gene characterisation}

The sequence of the carbonic anhydrase (CA) gene is 2947 bp in length and contains 5 coding exons of 408, 96, 79, 164 and 183 bp in length (Fig. 1). All the intron borders of CA start and end with the consensus GT and AG splicing signals, respectively. The corresponding amino acid sequence encodes a protein with a molecular weight of $32.97 \mathrm{kDa}$ and an isoelectric point of 6.65. The proximal promoter region (1034 bp) contained an identified TATA box (TATAAA), and several ATTTA(G) motifs (involved in mRNA stability) are present in the UTRs; there are three ATTTG and three ATTTA motifs in the 5'UTR and four ATTTA and three ATTTG motifs in the 3'UTR. We also found seven putative Nglycosylation motifs translating as Asn-Xaa-Thr/Ser in the coding region of D. labrax CA gene.

\subsection{Gene expression analysis}

Carbonic anhydrase. Carbonic anhydrase expression analysis in sea bass showed a tissue- and condition expression pattern. CA has a significantly higher expression level in gills than in intestine in saltwater acclimated fish and individuals from open sea (Fig. 2 and Table 6). In freshwater individuals (experimental and lagoon), CA expression is not significantly different between tissues (Fig. 2 and Table $6)$.

Claudin-3. Expression of claudin-3 (involved in cell-cell adhesion and regulation of solute transport) is not significantly different between the two organs studied (Fig. 3A and B). The claudin-3 mRNA expression exhibits a strong environmental effect in gill tissues (Fig. 3A). The expression is higher in open sea individuals than in those from lagoon.

$\mathrm{Na}^{+} / \mathrm{K}^{+}$-ATPase. This enzyme shows a strong tissue- and environmental-dependant expression. The expression is lower in open sea- than in lagoon-caught $D$. labrax in the two tissues but $\mathrm{Na}^{+} / \mathrm{K}^{+}$-ATPase is more expressed in gills than in intestine (Fig. 3A and B).

Angiotensin converting enzyme. The angiotensin converting enzyme is known to be involved in the activation of angiotensin I to active angiotensin II, a strong regulator of blood presure. The expression of this enzyme is not significantly different between tissues and fish origin (Fig. 3A and B).

Secretagogin. The secretagogin expression pattern (a protein involved in cell-cycle regulation through Ca-dependant processes) is strongly environment- and tissue-dependent. In the gills, expression is lower in open sea than in lagoon-originating fishes (Fig. 3A), while it shows an opposite trend in intestine (Fig.3B). We also observed that secretagogin expression is higher in intestine than in gills in individuals from the sea, and strongly higher in gills than in intestine in lagoonal individuals. We also identify two 
$\mathrm{Ca}^{2+}$-binding sites in the 388bp secretagogin partial cDNA sequence obtained in our SSH (GenBank accession no CX660758).

Nephrosin. Nephrosin is a secreted protease involved in immune function in fish. No significant nephrosin expression differences were observed between tissues. Open sea individuals showed a higher expression pattern than lagoonal individuals in intestine (Fig. 3B) but not in gill tissues (Fig. 3A). The nephrosin partial cDNA sequence obtained in the SSH (GenBank accession no CX660754) contains the specific zinc-binding motif generally observed in the astacin familly members HEXXHXXGFXHEXXRXDR.

\section{Discussion}

\subsection{Identification of salinity-regulated genes}

The SSH method has previously been used to identify up-regulated genes in teleost and mollusc species (Straub et al., 2004; Boutet et al., 2004) submitted to various environmental challenges, mostly pollutants. In the present report, we use the same method to characterise the transcriptomic response of a marine euryhaline teleost, the common (or European) sea bass D. labrax to salinity acclimation under experimental conditions. We obtained 586 different partial sequences of cDNA, encoding proteins involved in the metabolism of sea bass acclimated to saltwater and fresh water in two organs known to be involved in osmoregulation (intestine and gills).

\subsection{Molecular characterisation and expression of carbonic anhydrase.}

CA is an ubiquitous enzyme, catalysing the reversible hydration of $\mathrm{CO}_{2}$, and constitutes a family of zinc metalloenzymes found in nearly all organisms (Sly and Hu, 1995). These isozymes are found in many different tissues and are involved in a number of homeostatic processes, including carbon dioxide transport, ion exchange and acid-base balance (Geers and Gros, 2000). Because of both its general function and its universal presence in gill tissue of every species examined, CA is believed to be critical to the osmoregulatory function of the gills of all aquatic invertebrates (Henry, 1988). In this study, we characterised the complete sequence of the gene encoding $C A$ in D. labrax. The coding region of the $C A$ gene is interrupted by four introns. The $C A$ sequence exhibits multiple ATTTA(G) motifs in its untranslated regions. These motifs are known to be correlated with transcript stability (Shaw and Kamen, 1986), and have been found in other cDNAs (Fucci et al., 1995; Tanguy et al., 2005). We also observed seven putative N-glycosylation motifs Asn-Xaa-Thr/Ser (Marshall, 1974) in the coding region of $D$. labrax CA gene, as described in the mouse CA gene (Tamai et al., 1996).

We also investigated the CA mRNA expression in gills and intestine of sea bass acclimated to salt- or fresh water under experimental conditions. We observed that mRNA level is higher in gill of saltwaterthan freshwater-acclimated sea bass. Earlier studies conducted on the rainbow trout showed a higher $C A$ mRNA expression rate as well as higher enzyme activity in red blood cells than in all other tissues studied, such as kidney, gill or muscles (Esbaugh et al., 2004). Our study shows a higher expression of $C A$ in the gills than in the intestine. It is however noteworthy that the gill tissue contained numerous red blood cells which were not removed before RNA extraction. Our results also indicated that CA expression in gill (or gill and associated red blood cells) is higher in wild animals from higher salt concentrations. These results are in agreement with those reported for the in tilapia. In this species, Kültz et al. (1992) showed that CA and $\mathrm{Na}^{+} / \mathrm{K}^{+}$-ATPase activities are greatly increased under high salinity conditions. Flouders, however, did not show this regulation (Sender et al., 1999). These two studies measured CA activity levels. Our results suggest that the regulation of CA expression could be at the level of transcription, and possibly at the level of translation. It has been demonstrated that the large increase in CA activity in response to low-salinity exposure could be a result of regulatory processes operating at either the transcriptional or translational level in the green crab Carcinus maenas (Henry et al., 2003). Few other studies on $C A$ mRNA level in response to salinity variations are published to date. Hirata et al. (2003) studied CA mRNA in Osorezan dace (Tribolodon hakonensis) in response to acidic water conditions and showed that CA mRNA level is strongly increased in the gill and intestine, suggesting an important role of CA in acid adaptation. Further investigations are necessary to elucidate how CA mRNA 
expression intervenes in protein activity regulation (total translation into protein?) in $D$. labrax gills, but expression analysis of $C A$ in this organ seems to be a good indicator of fish from the sea.

\subsection{Osmoregulation genes expression in wild sea bass from the sea and the lagoon.}

Amongst the different genes encoding proteins involved in osmoregulation, we particularly focused on the $\mathrm{Na}^{+} / \mathrm{K}^{+}$-ATPase. This enzyme, present in branchial, renal and intestinal epithelia, plays an important role in maintaining osmotic homeostasis in freshwater- as well as saltwater-acclimated fish. Our study indicates a higher mRNA expression in lagoon-caught sea bass both in the gill and the intestine. Scott et al. (2004) explored the expression patterns of several genes encoding ion transport proteins in euryhaline killifish Fundulus heteroclitus after transfer from near-isosmotic brackish water [10 parts/thousand (ppt)] to either fresh water or saltwater. They demonstrated that many changes in response to saltwater transfer were transient. Increased mRNA expression occurred 1 day after transfer for the $\mathrm{Na}^{+} / \mathrm{K}^{+}$-ATPase- $\alpha 1$ a gene (3-fold). The responses to freshwater transfer were quite different from those to saltwater transfer. In particular, freshwater transfer increased $\mathrm{Na}^{+} / \mathrm{K}^{+}$-ATPase- $\alpha 1 \mathrm{a}$ mRNA expression and $\mathrm{Na}^{+} / \mathrm{K}^{+}$-ATPase activity to a greater extent than did transfer to saltwater (Scott et al., 2004). However few studies have attempted to determine wheter $\mathrm{Na}^{+} / \mathrm{K}^{+}$-ATPase $\alpha$-isoforms play a role in facilitating freshwater or seawater acclimation (Richards et al., 2003) and, in addition, there is discordance among studies in the degree and timing of changes in $\mathrm{Na}^{+} / \mathrm{K}^{+}$-ATPase activity, $\alpha$-subunit mRNA expression and protein abundance.

We also analysed expression pattern of claudin-3, a protein family involved in cell-cell adhesion through tight junctions (TJ) (Tsukita et al., 2001). TJ form a continuous intercellular seal that restricts and regulates the paracellular transport of water, small solutes, and immune cells (Heiskala et al., 2001). We observed a higher level of mRNA encoding this protein in individuals maintained in seawater in the laboratory (SSH, compared to freshwater acclimated fish) as well as in open sea-caught individuals. It has been suggested that tissue- and cell-type-specific expression of claudins determine the composition of the resulting intercellular complex and, in turn, the characteristic permeability properties observed for different epithelia and endothelia (Heiskala et al., 2001). While the intercellular seal provided by TJ acts as a barrier for the diffusion of large molecules, it allows the selective transport of water and, depending on the specific claudins, small solutes. Claudins 2 and 4, for example, have been linked to intercellular $\mathrm{Na}^{+}$and $\mathrm{K}^{+}$permeability (Amasheh et al., 2002), whereas claudin 16 is critical for renal re-absorption of $\mathrm{Ca}^{2+}$ and $\mathrm{Mg}^{2+}$ (Muller et al., 2003), indicating that claudins can function as highly selective paracellular ion channels.

Another enzyme studied in the present work is the angiotensin-converting enzyme (ACE). This enzyme, generally present in endothelia, plays a major role in the renin-angiotensin system (RAS) by converting angiotensin I (Ang I) to vasoactive angiotensin II (Ang II) (Olson, 1992). This system is involved in blood presure regulation in vertebrates. In euryhaline teleosts, circulating Ang II levels are higher in saltwater- than in freshwater-acclimated fish (Rankin et al, 2001; and references therein), indicating a possible role of RAS (and consequently of ACE) in osmoregulation in teleosts. Surprisingly, our analysis in wild sea bass indicated that there is no significant difference of levels of ACE mRNA expression between open sea and lagoon individuals in the gills.

Differential expression is not enough to conclude on the actual role of these proteins in the acclimation of D. labrax to various environmental conditions. However, our analysis provides a first basis for the development of osmoregulation markers amenable to quantitation in wild individuals.

\subsection{Genes involved in cell-cycle regulation}

We characterised several cDNA encoding proteins involved in cell-cycle regulation in sea bass as a response to salinity condition acclimatisation. We first examined the sequence encoding secretagogin and its expression in wild individuals. Secretagogin is a recently described member of the EF-hand $\mathrm{Ca}^{2+}$ binding protein involved in several Ca-dependant processes, cell-cycle regulation, development and apoptosis (Gartner et al., 2001 and references therein). The partial 388bp-secretagogin cDNA sequence obtained in our SSH library (up-regulated gene in gills of saltwater acclimated fish) contained two of the six characteristic $\mathrm{Ca}^{2+}$-binding sites described in human secretagogin gene (Wagner et al., 2000). Its 
mRNA expression is largely regulated by environmental factors in wild sea bass. In $D$. labrax from the sea, secretagogin mRNA is more abundant in the intestine than in the gills, while an opposite pattern is observed in individuals from Ingril lagoon. Recent studies on human indicated that secretagogin is abundantly expressed (mRNA) and secreted in central nervous system and neuroendocrine cells and to a minor extent in intestine, colon and stomach (Zhan et al., 2003). Its expression in pancreas is specific to the islets, and it is thought to be involved in KCl-stimulated calcium flux and the regulation of cell proliferation. The current study highlights the potential importance of this newly described protein, whose function has been little studied (Cras-Meuneur et al., 2004). Our results indicate that cell-cycle regulation seems to be potentially dependant on salinity conditions in sea bass acclimated to salt- and fresh water. Interestingly, it is the first report a regulation of secretagogin at a transcriptomic level in fish on one hand and in another organ than pancreas, the gills, on the other hand.

\subsection{The case of nephrosin, a gene potentially involved in regulation of immune system}

Nephrosin is a newly discovered member of the astacin family. It is a secreted proteinase and is present in carp head kidney, posterior kidney, and spleen, all of which are responsible for immune and haematopoietic functions in fish (Tsai et al., 2004). We characterised nephrosin as an upregulated gene in gill of saltwater acclimated sea bass. The partial D. labrax nephrosin sequence obtained in our SSH (GenBank accession $\mathrm{N}^{\circ}$ CX660754) contains the specific zinc binding motif generally observed in the astacin familly members HEXXHXXGFXHEXXRXDR (Hung et al., 1997), indicating that this partial cDNA encodes nephrosin in sea bass. Our semi-quantitative RT-PCR expression analysis indicated a similar level of nephrosin mRNA in gill and intestine and a higher intestinal expression rate in individuals from the sea than those from Ingril lagoon. In zebrafish, it has been demonstrated that nephrosin is specifically expressed in granulocytes (Song et al., 2004). Our SSH results support the activation of the immune system by salinity variations in sea bass. Some hormones involved in osmoregulation, such as prolactin (PRL) and growth hormone (GH) are known to enhance immune functions in fish as in mammals (Harris and Bird 2000). The phagocytic activity of fish leucocytes is stimulated by administration of PRL or GH (Harris and Bird 2000). In salmonids, the immunomodulatory effect of GH seems to be related to its role in osmoregulation. We have observed an increase of PRL mRNA in gill of sea bass from Ingril lagoon (Boutet et al., unpublished data). The indirect effect of environmental salinity and osmoregulatory hormones on the immune systems could be used as a potential marker of acclimatisation or migration of sea bass to new environmental conditions generally observed in lagoon and during the fish life-cycle.

\section{Conclusion}

Osmoregulatory mechanisms and acclimation to salinity environmental conditions in euryhaline fishes are known to be under control of hormonal factors such as prolactin and cortisol. In euryhaline teleosts, these hormones increase in plasma levels usually within a few days after freshwater or seawater entry and seem to drive the osmoregulatory system into the appropriate direction. Previously described differentially expressed proteins (Sakamoto et al., 2001; and references therein) may play a role for the subsequent survival of the fish, although changes in mRNA levels do not necessarily reflect different amounts of the encoded proteins. The salinity-regulated genes characterised in the present study, which mRNA levels in gill and intestine change according to environmental conditions, may serve as convenient entry points to study the molecular basis of environmental adaptation. The physiological role of many of theses genes in environmental adaptation remains to be explored. A further step would be to address the question of how the environmental factors trigger regulation of expression of these genes. Identification of regulation polymorphisms should be performed as a next step to understand the basis of interindividual variation to salinity response observed in this species.

\section{Acknowledgements}

The post-doctoral position of I. Boutet was funded by IFREMER (lagunogenomix program). The authors would like to thank S. Hourdez for helpful english corrections, J. Picot at the Syndicat Intercommunal des Etangs Littoraux (Frontignan, France) for providing physico-chemical data of the Ingril lagoon in 2004, M. Cantou (Innovaqua, SMEL, Sète) for providing wild fishes used in this study, 
C. Nebel for sharing experimental fish and B. Guinand for constant help and discussion throughout this study. People from the IFREMER biological station at Palavas-les-Flots are also greatly acknowledged. This project was partially funded by the network of excellence Marine Genomics Europe.

\section{References}

Alderdice, D.F., 1988. Osmotic and ionic regulation in teleost eggs and larvae. In: Hoar, W.S., Randall, D.J. (Eds.), Fish physiology, vol XI. The physiology of developing fish, part A. Eggs and larvae. Academic press, New York, pp. 163-242.

Allegrucci, G., Caccone, A., Cataudella, S., Powell, J., Sbordoni, V., 1995. Acclimation of the European sea bass to freshwater: monitoring genetic changes by RAPD polymerase chain reaction to detect DNA polymorphisms. Mar. Biol. 121, 591-599.

Amsheh, S., Meiri, A.H., Gitter, T., Schöneberg, J., Mankertz, J.D., Schulzke, M., Fromm, J., 2002. Claudin-2 expression induces cation-selective channels in tight junctions of epithelial cells. J. Cell Sci. 115, 4969-4976.

Barnabé, G., 1980. Exposé synoptique des données biologiques sur le loup ou bar, Dicentrarchus labrax. Synop. FAO Pêches 126-170.

Boutet, I., Tanguy, A., Moraga, D., 2004. Response of the Pacific oyster Crassostrea gigas to hydrocarbon contamination under experimental conditions. Gene 329, 147-157.

Cras-Meneur, C., Inoue, H., Zhou, Y., Ohsugi, M., Bernal-Mizrachi, E., Pape, D., Clifton, S.W., Permutt, M.A., 2004. An expression profile of human pancreatic islet mRNAs by Serial Analysis of Gene Expression (SAGE). Diabetologia 47, 284-299.

Esbaugh, A.J., Lund, S.G., Tufts, B.L., 2004. Tufts Comparative physiology and molecular analysis of carbonic anhydrase from the red blood cells of teleost fish. J. Comp. Physiol. 174B, 429-438.

Forsyth, I.A., Wallis, M., 2002. Growth hormone and prolactin--molecular and functional evolution. J. Mammary Gland Biol. Neoplasia 7, 291-312.

Freeman, M.E., Kanyicska, B., Lerant, A., Nagy, G., 2000. Prolactin: structure, function, and regulation of secretion. Physiol. Rev. 80, 1523-1631.

Fucci, L., Piscopo, A., Aniello, F., Branno, M., Di Gregorio, A., Calogero, R., Geraci, G., 1995. Cloning and characterization of a developmentally regulated sea urchin cDNA encoding glutamine synthetase. Gene 152, 205-208.

Gartner, W., Lang, W., Leutmetzer, F., Domanovits, H., Waldhausl, W., Wagner, L., 2001. Cerebral expression and serum detectability of secretagogin, a recently cloned EF-hand Ca(2+)-binding protein. Cereb. Cortex 11, 1161-1169

Geers, C., Gros, G., 2000. $\mathrm{CO}_{2}$ transport and carbonic anhydrase in blood and muscle. Physiol. Rev. 80, 681-715.

Harris, J., Bird, D.J., 2000. Modulation of the fish immune system by hormones. Vet. Immunol. Immunopath. 77, 163-176.

Heiskala, M., Peterson, P.A., Yang, Y., 2001. The roles of claudin superfamily proteins in paracellular transport. Traffic 2, 93-98.

Henry, R.P., 1988. Subcellular distribution of carbonic anhydrase activity in the gills of the gills of the blue crab, Callinectes sapidus. J. Exp. Zool. 245, 1-8.

Henry, R.P., Gehnrich, S., Weihrauch, D., Towle, D.W., 2003. Salinity-mediated carbonic anhydrase induction in the gills of the euryhalin green crab, Carcinus menas. Comp. Biochem. Physiol. 136, 243-258.

Hirata, T. et al., 2003. Mechanism of acid adaptation of a fish living in a pH 3.5 lake. Am. J. Physiol. Regul. Integr. Comp. Physiol. 284, R1199-R1212.

Hirose, S., Kaneko, T., Naito, N., Takei, Y., 2003. Molecular biology of chloride cells. Comp. Biochem. Physiol. 136B, 593-620.

Hung, C.H., Huang, H.R., Huang, C.J., Huang, F.L., Chang, G.D., 1997. Purification and cloning of carp nephrosin, a secreted zinc endopeptidase of the astacin family. J. Biol. Chem. 272, 13772-13778.

Jensen, M.K., Madsen, S.S., Kristiansen, K., 1998. Osmoregulation and salinity effects on the expression and activity of $\mathrm{Na}^{+} / \mathrm{K}^{+}$-ATPase in the gills of European sea bass, Dicentrarchus labrax (L.). J. Exp. Zool. 282, 290-300. 
Kültz, D., Bastrop, R., Jürss, K., Siebers, D., 1992. Mitochondria-rich (MR) cells and the activities of $\mathrm{Na}^{+} / \mathrm{K}^{+}$-ATPase and carbonic anhydrase in the gill and opercular epithellium of Oreochromis mossambicus adapted to various salinities. Comp. Biochem. Physiol. 102B, 293-301.

Lemaire, C., Allegrucci, G., Naciri, M., Bahri-Sfar, L., Kara, H., Bonhomme, F., 2000. Do discrepancies between microsatellite and allozyme variation reveal differential selection between sea and lagoon in the sea bass (Dicentrarchus labrax)? Mol. Ecol. 9, 457-467.

Marshall, R.D., 1974. The nature and metabolism of the carbohydrate-peptide linkages of glycoproteins. Biochem. Soc. Symp. 40, 17-26.

Muller, D., Kausalya, P.J., Claverie-Martin, F., Meij, I.C., Eggert, P., Garcia-Nieto, V., Hunziker, W., 2003. A novel claudin 16 mutation associated with childhood hypercalciuria abolishes binding to ZO-1 and results in lysosomal mistargeting. Am. J. Hum. Genet. 73, 1293-1301.

Nebel, C., Romestand, B., Nègre-Sadargues, G., Grousset, E., Aujoulat, F., Bacal, J., Bonhomme, F., Charmantier, G., 2005. Differential freshwater adaptation in juvenile sea-bass Dicentrarchus labrax: involvement of gills and urinary system. J. Exp. Biol. 208, 3859-3871.

Olson, K.R., 1992. Blood and extracellular fluid volume regulation: role of the renin-angiotensin, kallikrenin-kinin systems and natriuretic peptides. In: Hoar, W.S., Randall, D.J., Farrell, A.P. (Ed.), Fish physiology, vol 12B. pp 135-254.

Rankin, J.C., Cobb, C.S., Frankling, S.C., Brown, J.A., 2001. Circulating angiotensins in the river lamprey, Lampetra fluviatilis, acclimated to freshwater and seawater: possible involvement in the regulation of drinking. Comp. Biochem. Physiol. 129B, 311-318.

Richards, J.G., Semple, J.W., Bystriansky, J.S., Schulte, P.M., 2003. Na+/K+-ATPase alpha-isoform switching in gills of rainbow trout (Oncorhynchus mykiss) during salinity transfer. J. Exp. Biol. 206, 4475-4486.

Sakamoto, T., Uchida, K., Yokota, S., 2001. Regulation of the ion-transporting mitochondrion-rich cell during adaptation of teleost fishes to different salinities. Zoolog. Sci. 18, 1163-1174.

Scott, G.R., Richards, J.G., Forbush, B., Isenring, P., Schulte, P.M., 2004. Changes in gene expression in gills of the euryhaline killifish Fundulus heteroclitus after abrupt salinity transfer. Am. J. Physiol. Cell Physiol. 287, C300-C309.

Sender, S., Böttcher, K., Cetin, Y., Gros, G., 1999. Carbonic anhydrase in the gills of seawater- and freshwater-acclimated flounders Platichthys flesus: purification, characterisation, and immunohistochemical localization. J. Histochem. Cytochem. 47, 43-50.

Shaw, G., Kamen, R.A., 1986. Conserved AU sequence from the 3' untranslated region of GM-CSF mRNA mediates selective mRNA degradation. Cell 46, 659-667.

Sly, W.S., Hu, P.Y., 1995. Human carbonic anhydrases and carbonic anhydrase deficiencies. Annu. Rev. Biochem. 64, 375-401.

Song, H.D. et al, 2004. Hematopoietic gene expression profile in zebrafish kidney marrow. Proc. Natl. Acad. Sci. U.S.A. 101, 16240-16245.

Straub, P.F., Higham, M.L., Tanguy, A., Landau, B.J., Phoel, W.C., Stanton Hales Jr, L., Thwing, T.K.M., 2004. Suppression subtractive hybridisation cDNA libraries to identify differentially expressed genes from constrating fish habitats. Mar. Biotechnol. 6, 386-399.

Streelman, J.T., Kocher, T.D., 2002. Microsatellite variation associated with prolactin expression and growth of salt-challenged tilapia. Physiol. Genomics 9, 1-4.

Tamai, S., Waheed, A., Cody, L.B., Sly, W.S., 1996. Gly-63 $\rightarrow$ Gln substitution adjacent to His-64 in rodent carbonic anhydrase IVs largely explains their reduced activity. Proc. Natl. Acad. Sci. U.S.A. 93, 13647-13652.

Tanguy, A., Boutet, I., Moraga, D., 2005. Molecular characterisation of glutamine synthetase gene in the Pacific oyster Crassostea gigas: expression study in response to xenobiotic exposure and developmental stage. Biochim. Biophys. Acta 1681, 116-125.

Tipsmark, C.K., Madsen, S.S., Seidelin, M., Christensen, A.S., Cutler, C.P., Cramb, G., 2002. Dynamics of $\mathrm{Na}(+), \mathrm{K}(+), 2 \mathrm{Cl}(-)$ cotransporter and $\mathrm{Na}(+), \mathrm{K}(+)$-ATPase expression in the branchial epithelium of brown trout (Salmo trutta) and Atlantic salmon (Salmo salar). J. Exp. Zool. 293, 106-118.

Tsai, P.L., Chen, C.H., Huang, C.J., Chou, C.M., Chang, G.D., 2004. Purification and cloning of an endogenous protein inhibitor of carp nephrosin, an astacin metalloproteinase. J. Biol. Chem. 279, 11146-11155. 
Tsukita, S., Furuse, M., Itoh, M., 2001. Multifunctional strands in tight junctions. Nat. Rev. Mol. Cell. Biol. 2, 285-293.

Varsamos, S., Connes, R., Diaz, J.P., Barnabé, G., Charmantier, G., 2001. Ontogeny of osmoregulation in the European sea bass Dicentrarchus labrax L. Mar. Biol. 138, 909-915.

Varsamos, S., Diaz, J.P., Charmantier, G., Flik, G., Blasco, C., Connes, R., 2002. Branchial chloride cells in sea bass (Dicentrarchus labrax) adapted to fresh water, seawater, and doubly concentrated seawater. J. Exp. Zool. 293, 12-26.

Wagner, L., Oliyarnyk, O., Gartner, W., Nowotny, P., Groeger, M., Kaserer, K., Waldhäusl, W., Pasternack, M.S., 2000. Cloning and expression of secretagogin, a novel neuroendocrine and pancreatic islet of Langerhans-specific $\mathrm{Ca}^{2+}$-binding protein. J. Biol. Chem. 275, 24740-24751.

Weber, G.M., Seale, A.P., Richman III, N.H., Stetson, M.H., Hirano, T., Grau, E.G., 2004. Hormone release is tied to changes in cell size in the osmoreceptive prolactin cell of a euryhaline teleost fish, the tilapia, Oreochromis mossambicus. Gen. Comp. Endocrinol. 138, 8-13.

Zhan, X., Evans, C.O., Oyesiku, M.N., Desirerio, M., 2003. Proteomics and transcriptomics analysis of secretagogin down-regulation in human non-functional pituitary adenomas. Pituitary 6, 189-202. 
Table 1. Combinations of primers used in semi-quantitative RT-PCR expression analysis and optimal number of PCR cycles (analysis in exponential phase).

\begin{tabular}{|c|c|c|}
\hline Genes & $\begin{array}{l}\text { Optimal number } \\
\text { of PCR cycles }\end{array}$ & Primer sequences \\
\hline Carbonic anhydrase & 40 & $\begin{array}{l}\text { sense GATGGAAAGCGCTATCCCATGGAGTTACA } \\
\text { antisense CCTGTAAACTTAGTGCAAGTGCATTCCTGCC }\end{array}$ \\
\hline $\begin{array}{l}\text { Angiotensin- } \\
\text { converting enzyme }\end{array}$ & 30 & $\begin{array}{l}\text { sense GGGCCTCTACATACCTGCGACATCTA } \\
\text { antisense CCAAGGCTTACTGAAGCCCAGCTTCAT }\end{array}$ \\
\hline $\mathrm{Na}^{+} / \mathrm{K}^{+}$-ATPase & 35 & $\begin{array}{l}\text { sense GACATCATGAAGAGACAGCCCAGAAA } \\
\text { antisense GCCAGAGCTGTCTCCTCAAACAGTCC }\end{array}$ \\
\hline Claudin-3 & 25 & $\begin{array}{l}\text { sense GTGGTGATCGATGCCCAGCGCAGGGA } \\
\text { antisense TGGGTTCGGGGAGCATGGCGGCACAG }\end{array}$ \\
\hline Secretagogin & 30 & $\begin{array}{l}\text { sense GACTTGGCCAGGATCTTGGCTTTAGA } \\
\text { antisense GGTTTAGGTTTGACTCCAAGACACAG }\end{array}$ \\
\hline Nephrosin & 40 & $\begin{array}{l}\text { sense CCCTGCACTGCCAGAGGATGCAAGTGG } \\
\text { antisense ACACGAGCAATGTCATTGACACTCAT }\end{array}$ \\
\hline $28 S$ ribosomal DNA & 25 & $\begin{array}{l}\text { sense CTCAGTAGCGGCGAGCGAAGAGGGAAG } \\
\text { antisense AGGTACTTGTCGACTATCGGTCTCGTG }\end{array}$ \\
\hline
\end{tabular}


Table 2. Identified SSH up-regulated clones in intestine of freshwater-acclimated fishes.

\begin{tabular}{|c|c|}
\hline Homolog (protein); blastx value & GenBank accession no \\
\hline \multicolumn{2}{|l|}{ Osmoregulation (2.6\%) } \\
\hline Aquaporin; 3e-20 & CX660607 \\
\hline Thiazide-sensitive Na-Cl cotransporter; 3e-30 & CX660616 \\
\hline Angiotensin-converting enzyme; 2e-45 & CX660620 \\
\hline Amiloride binding protein $1 ; 4 \mathrm{e}-46$ & CX660623 \\
\hline \multicolumn{2}{|l|}{ Cell cycle regulation (1.9\%) } \\
\hline Tpt-1 protein; $2 \mathrm{e}-16$ & CX660591 \\
\hline Protein tyrosine phosphatase; 3e-05 & CX660603 \\
\hline gastrula specific embryonic protein 1 ; 6e-11 & CX660609 \\
\hline \multicolumn{2}{|l|}{ Cytoskeleton (0.6\%) } \\
\hline Myosin light chain alkali ; 8e-74 & CX660592 \\
\hline \multicolumn{2}{|l|}{ Energetic metabolism and respiratory chain (4.5\%) } \\
\hline Cytochrome c oxidase subunit Va; 2e-29 & CX660594 \\
\hline Cytochrome c oxidase subunit III; 0.001 & CX660445 \\
\hline Cytochrome c oxidase subunit I; 5e-24 & CX660601 \\
\hline Cytochrome b; 6e-78 & CAA57262 \\
\hline Fructose-biphosphate aldolase B; 2e-67 & CX660600 \\
\hline Succinate dehydrogenase C; 7e-26 & CX660602 \\
\hline Glyceraldehyde-3-phosphate dehydrogenase; 2e-05 & CX660611 \\
\hline \multicolumn{2}{|l|}{ Protein regulation (1.3\%) } \\
\hline Spermidine/spermine N1-acetyltransferase ; 7e-16 & CX660595 \\
\hline Alpha-aspartyl dipeptidase ; 3e-27 & CX660615 \\
\hline \multicolumn{2}{|l|}{ Lipid metabolism (3.2\%) } \\
\hline Very-long-chain acyl-coA synthetase; 3e-70 & CX660598 \\
\hline Intestinal fatty acid binding protein; 6e-18 & CX660610 \\
\hline Soluble epoxide hydrolase; $1 \mathrm{e}-08$ & CX660617 \\
\hline C1q-like adipose specific protein; 7e-11 & CX660618 \\
\hline Cellular retinol-binding protein 1; 6e-22 & CX660621 \\
\hline \multicolumn{2}{|c|}{ Cell communication, immune system, cell protection (3.2\%) } \\
\hline Antifreeze protein LS-12; 3e-26 & CX660592 \\
\hline X-transporter protein 2; 1e-66 & CX660597 \\
\hline Activated protein kinase C; $2 \mathrm{e}-60$ & CX660599 \\
\hline Hexosaminidase B; 2e-37 & CX660606 \\
\hline Elastase 1; 9e-67 & CX660608 \\
\hline \multicolumn{2}{|l|}{ Detoxification (2.6\%) } \\
\hline Glutathione S-transferase theta 3; 8e-46 & CX660604 \\
\hline Peroxiredoxin 5; 3e-11 & CX660613 \\
\hline Aflatoxin B1 aldehyde reductase; 8e-17 & CX660614 \\
\hline Ferritin H; 5e-72 & CX660619 \\
\hline \multicolumn{2}{|l|}{ Nucleic acid regulation (0.6\%) } \\
\hline Elongation factor-2; 1e-35 & CX660612 \\
\hline Ribosomal proteins (5.8\%) & CX660734-CX660742 \\
\hline Unidentified sequences $^{\mathrm{a}}$ (73.4\%) & CX660624-CX660733 \\
\hline
\end{tabular}

\footnotetext{
${ }^{\mathrm{a}}$ Sequences presented no significant alignment $(<0.001)$ or significant alignment with an unknown protein.
} 
Table 3. Identified SSH up-regulated clones in intestine of seawater-acclimated fishes.

\begin{tabular}{ll}
\hline Homolog (protein); blastx value & GenBank accession no \\
\hline $\begin{array}{l}\text { Cytoskeleton (0.7\%) } \\
\text { Myosin light chain 4; 2e-51 }\end{array}$ & CX660886 \\
& \\
Energetic metabolism and respiratory chain (2.2\%) & \\
Cytochrome c oxidase subunit Vb; 8e-49 & CX660885 \\
Glucosamine-6-phosphate deaminase; e-106 & CX660894 \\
ATP synthase FO subunit 6; 4e-31 & CX660904 \\
Protein regulation (3.6\%) & \\
Solute carrier family 15; 4e-13 & CX660890 \\
Proteasome subunit beta 3; 2e-62 & CX660895 \\
Dipeptidylpeptidase 4b; 2e-85 & CX660897 \\
Aminopeptidase N; 1'-37 & CX660898 \\
Cystatin; 3e-19 & CX660899 \\
Lipid metabolism (0.7\%) & \\
Apolipoprotein B; 5e-07 & CX660896 \\
Cell communication, immune system, cell protection (5.1\%) & \\
Notch 2; 5e-08 & \\
Immune-associated nucleotide-binding protein 9; 1e-05 & CX660886 \\
Uromodulin; 5e-08 & CX660888 \\
Major histocompatibility complex class I; 2e-13 & CX660891 \\
Antifreeze polypeptide; 3e-09 & CX660892 \\
serum lectin isoform 2; 1e-08 & CX660900 \\
Small inducible cytokine; 2e-23 & CX660902 \\
Detoxification (0.7\%) & CX660904 \\
Cu/Zn superoxide dismutase; 2e-78 & \\
Unidentified sequences ${ }^{\mathrm{a}}$ (86.9\%) & CX660893 \\
\hline Seq & \\
\end{tabular}

${ }^{a}$ Sequences presented no significant alignment $(<0.01)$ or significant alignment with an unknown protein. 
Table 4: Identified SSH up-regulated clones in gills of freshwater-acclimated fishes.

\begin{tabular}{|c|c|}
\hline Homolog (protein); blastx value & GenBank accession no \\
\hline \multicolumn{2}{|l|}{ Osmoregulation (0.7\%) } \\
\hline $\mathrm{Na}+\mathrm{K}+$ ATPase alpha $4 ; 7 \mathrm{e}-81$ & CX660460 \\
\hline \multicolumn{2}{|l|}{ Cell cycle regulation $(0.7 \%)$} \\
\hline Neural proliferation differenciation and control protein 1; 5e-11 & CX660470 \\
\hline \multicolumn{2}{|l|}{ Cytoskeleton (4.6\%) } \\
\hline Cytokeratin; 2e-70 & CX660438 \\
\hline Keratin 18; 5e-17 & CX660441 \\
\hline Gelsolin; 6e-28 & CX660443 \\
\hline Collagen type I alpha 2; 7e-13 & CX660451 \\
\hline Type I keratin S8; 5e-09 & CX660454 \\
\hline Type I keratin E7; 6e-04 & CX660461 \\
\hline Type II basic cytokeratin; 3e-73 & CX660466 \\
\hline \multicolumn{2}{|l|}{ Energetic metabolism and respiratory chain (2\%) } \\
\hline Isocitrate dehydrogenase; $6 \mathrm{e}-42$ & CX660439 \\
\hline ATP synthase c-subunit; 4e-42 & CX660449 \\
\hline Ecto-ATPase; 4e-12 & CX660457 \\
\hline \multicolumn{2}{|l|}{ Protein regulation (1.3\%) } \\
\hline Arginase; 5e-19 & CX660463 \\
\hline Ornithine decarboxylase antizyme small isoform; 7e-10 & CX660465 \\
\hline \multicolumn{2}{|l|}{ Cell communication, immune system, cell protection (7.9\%) } \\
\hline MHC class II alpha; 2e-62 & CX660440 \\
\hline class I helical cytokine receptor number 26; 3e-07 & CX660444 \\
\hline tetraspan 3; 1e-33 & CX660447 \\
\hline Alpha 3-fucosyltransferase; 2e-51 & CX660452 \\
\hline Receptor for activited kinase C; 2e-75 & CX660453 \\
\hline Cathepsin; 9e-53 & CX660458 \\
\hline JAK1 tyrosin kinase; 6e-05 & CX660459 \\
\hline Ficolin; 3e-10 & CX660462 \\
\hline Growth factor independence-1B; 3e-09 & CX660464 \\
\hline Integrin beta 4 ; $1 \mathrm{e}-62$ & CX660467 \\
\hline Regulator of G-protein signalling 4; 2e-14 & CX660468 \\
\hline Lymphocyt protein tyrosin kinase; 1e-19 & CX660471 \\
\hline \multicolumn{2}{|l|}{ Detoxification (0.7\%) } \\
\hline Glutathione peroxidase; $1 \mathrm{e}-70$ & CX660442 \\
\hline \multicolumn{2}{|l|}{ Nucleic acid regulation (3.3\%) } \\
\hline Splicing factor 3B; 1e-37 & CX660437 \\
\hline eukaryotic translation initiation factor 3 ; 1e-72 & CX660446 \\
\hline Int-6 protein; $1 \mathrm{e}-32$ & CX660450 \\
\hline Nuclease diphosphate kinase B; 5e-69 & CX660455 \\
\hline Signalosome component COPS2; 3e-38 & CX660469 \\
\hline Ribosomal proteins (3.3\%) & CX660586-CX660590 \\
\hline Unidentified sequences ${ }^{\mathrm{a}}$ (75.5\%) & CX660472-CX660585 \\
\hline
\end{tabular}

\footnotetext{
${ }^{\mathrm{a}}$ Sequences presented no significant alignment $(<0.01)$ or significant alignment with an unknown protein.
} 
Table 5: Identified SSH up-regulated clones in gills of seawater-acclimated fishes.

\begin{tabular}{|c|c|}
\hline Homolog (protein); blastx value & GenBank accession no \\
\hline \multicolumn{2}{|l|}{ Osmoregulation (2.1\%) } \\
\hline Claudin 3; 3e-05 & CX660743 \\
\hline Carbonic anhydrase 4; 8e-17 & CX660749 \\
\hline Endothelin receptor A; 2e-25 & CX660777 \\
\hline \multicolumn{2}{|l|}{ Cell cycle regulation (4.2\%) } \\
\hline Pescadillo; 1e-53 & CX660747 \\
\hline PTTG-binding factor; 2e-14 & CX660750 \\
\hline Chromosome segregation protein SMC1; 2e-40 & CX660756 \\
\hline Vesicle-associated membrane protein; 5e-41 & CX660764 \\
\hline Caspase 3; 1e-59 & CX660770 \\
\hline Secretagogin; 1e-43 & CX660758 \\
\hline \multicolumn{2}{|l|}{ Cytoskeleton (2.1\%) } \\
\hline Beta actin; 5e-28 & CX660456 \\
\hline Alpha-tubulin; 1e-34 & CX660448 \\
\hline Type II keratin E3; 3e-93 & CX660773 \\
\hline \multicolumn{2}{|l|}{ Energetic metabolism and respiratory chain (1.4\%) } \\
\hline Mitochondrial ATP synthase gamma subunit; 8e-63 & CX660761 \\
\hline Cytochrome c oxidase subunit III; 1e-42 & CX660445 \\
\hline \multicolumn{2}{|l|}{ Protein regulation (3.5\%) } \\
\hline Ubiquitin like protein; 8e-35 & CX660748 \\
\hline Epidermis specific serine protease; $8 \mathrm{e}-31$ & CX660751 \\
\hline Protein disulfide isomerase related protein; 1e-29 & CX660755 \\
\hline Rhomboid, veinlet-like 2; 4e-61 & CX660757 \\
\hline Importin 7; 3e-90 & CX660769 \\
\hline \multicolumn{2}{|c|}{ Cell communication, immune system, cell protection (10.5\%) } \\
\hline Chemokine ligand 4; 6e-09 & CX660744 \\
\hline Mpx protein; 2e-51 & CX660745 \\
\hline RW1 protein; 3e-18 & CX660746 \\
\hline Interferon regulatory factor; $1 \mathrm{e}-60$ & CX660752 \\
\hline GDP dissociation inhibitor 2; 8e-31 & CX660759 \\
\hline RHCG-2; 3e-74 & CX660762 \\
\hline Glutamic acid-rich protein; 3e-07 & CX660763 \\
\hline IFN-inducible and antiviral protein; 1e-55 & CX660765 \\
\hline ISG12 protein; 7e-05 & CX660766 \\
\hline Ovary-specific C1q-like factor; 6e-15 & CX660767 \\
\hline Cadherin 1; 9e-29 & CX660768 \\
\hline Protective protein for beta-galactosidase; 8e-38 & CX660771 \\
\hline VHSV-induced protein-3; 3e-05 & CX660775 \\
\hline Rab-7; 2e-24 & CX660776 \\
\hline Nephrosin; 3e-31 & CX660754 \\
\hline \multicolumn{2}{|l|}{ Detoxification $(0.7 \%)$} \\
\hline Glutathione S-transferase; 2e-33 & CX660774 \\
\hline \multicolumn{2}{|l|}{ Nucleic acid regulation (1.4\%) } \\
\hline RNA helicase-DEAD box protein; 9e-22 & CX660753 \\
\hline Nuclear matrix protein NXP2; 9e-51 & CX660772 \\
\hline Ribosomal proteins (2.1\%) & CX660882-CX660884 \\
\hline Unidentified sequences $^{\mathrm{a}}$ (72.2\%) & CX660778-CX660881 \\
\hline
\end{tabular}

\footnotetext{
${ }^{\mathrm{a}}$ Sequences presented no significant alignment $(<0.01)$ or significant alignment with an unknown protein.
} 
Table 6. Summary of the results obtained in expression analysis of carbonic anhydrase in wild and experimental individuals.

\begin{tabular}{lcc}
\cline { 2 - 3 } SW / FW & Gill & Intestine \\
\hline SW / Sea & $*$ & $*$ \\
SW / Lag & NS & $*$ \\
FW / Sea & $*$ & $\mathrm{NS}$ \\
FW / Lag & $*$ & $\mathrm{NS}$ \\
Sea / Lag & $*$ & $*$ \\
\hline (NS) non significant. (*) significant (P<0.05). (SW) saltwater acclimated fish. (FW) \\
freshwater acclimated fish. (Sea) fish from open Mediterranean sea. (Lag) fish from Ingril \\
Lagoon.
\end{tabular}


Fig. 1. Nucleotide sequence of carbonic anhydrase gene of D. labrax. The coding region is in upper case and the non-coding regions are in lower case. The corresponding amino acid sequence is bold characters. Identified TATA box is boxed, ATTTA(G) motifs (involved in mRNA stability) are underlined and putative N-glycosylation motifs Asn-Xaa-Thr/Ser are double-underlined. 
actactagcagcaactccagtaaaatattatagtttctggaaattaagctgataacacctactacaactacc atactactgtgtaaattgtatttcattcagtcatgtttgtggttctagactcagaacctgttaacatgtttt ttgctactcaaagaagaacagtgaagtgggacccttgattgatccctgaatgttgtaaatagaaataatact tcctggaactatacacccacatgaatagtcaggaacgcaaccaggaat taaagttctactt taatactaacc tcaaaacccaagttctgttgcttcctgcagctcgacggagctttatagtgaacttcacctcattgtttagc tgttagaccacaactttaatgttttggtccaggctcacaaccctcttagtgtcatttatggctgttttcagt gcaaacgctatacaagccgaacgttcagctcagcaccaaattgctgacagacacagttaaccactagagaga gagatttgaggatatgaactagtttctgggttcctggaaaaatccttgtggatgaaacaaagatccaaacat cacctgggtttggaaatgccatttactcctgttt tataaalcagtagcctacgttgtttgatgcttaataaa taaatacgtgtgtttttaacattttaaagattttaaaattcatacaaaatttgagtttatcttatttttaa actggctgcaattraatttactgtgtaatttatttgcataaacctacacttgcaatactgctgtcagatt atgcttcctgttattactcattcatccatacctatgcatgtttaaacaaataaataaacaaaaaacaaata cctcctctgcttattagccccagaacattttcaggaagctaatggccaagtcagatgtcacatagaggcag tgttagacagctgggggttgcctgagcgaataataaggggaggaggatgaggccetttagccattagcggac $\begin{array}{lccccccccccc} & \mathbf{M} & \mathbf{N} & \mathbf{W} & \mathbf{L} & \mathbf{V} & \mathbf{A} & \mathbf{A} & \mathbf{L} & \mathbf{A} & \mathbf{V} & \mathbf{C} \\ \text { actgaggaggtacaggtgcgtcaaag } & \text { ATG } & \text { AAC } & \text { TGG } & \text { CTT } & \text { GTA } & \text { GCT } & \text { GCG } & \text { CTT } & \text { GCT } & \text { GTG } & \text { TGC }\end{array}$

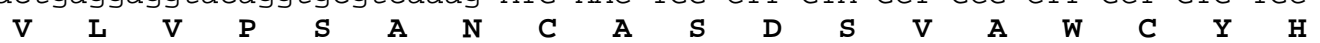
GTC CTA GTG CCC AGC GCA AAC TGT GCT TCA GAC TCA GTC GCC TGG TGT TAT CAT $\begin{array}{llllllllllllllllll}\mathbf{Q} & \mathbf{P} & \mathbf{S} & \mathbf{C} & \mathbf{N} & \mathbf{D} & \mathbf{T} & \mathbf{T} & \mathbf{W} & \mathbf{P} & \mathbf{T} & \mathbf{I} & \mathbf{A} & \mathbf{A} & \mathbf{K} & \mathbf{Y} & \mathbf{C} & \mathbf{N}\end{array}$ CAG CCA AGC TGC AAT GAC ACT ACC TGG CCA ACC ATC GCT GCT AAG TAT TGC $\underline{\underline{\text { AAT }}}$ $\begin{array}{llllllllllllllllllllll}\mathbf{G} & \mathbf{T} & \mathbf{R} & \mathbf{Q} & \mathbf{S} & \mathbf{P} & \mathbf{I} & \mathbf{N} & \mathbf{I} & \mathbf{V} & \mathbf{S} & \mathbf{A} & \mathbf{S} & \mathbf{A} & \mathbf{E} & \mathbf{P} & \mathbf{N} & \overline{\mathbf{A}}\end{array}$ GGC ACC CGA CAG TCT CCC ATT AAC ATC GTC TCA GCA TCT GCG GAA CCT AAC GCC \begin{tabular}{cccccccccccccccccc}
\hline \hline $\mathbf{N}$ & $\mathbf{L}$ & $\mathbf{T}$ & $\mathbf{E}$ & $\mathbf{F}$ & $\mathbf{T}$ & $\mathbf{F}$ & $\mathbf{Q}$ & $\mathbf{N}$ & $\mathbf{Y}$ & $\mathbf{G}$ & $\mathbf{D}$ & $\mathbf{T}$ & $\mathbf{S}$ & $\mathbf{I}$ & $\mathbf{L}$ & $\mathbf{K}$ & $\mathbf{K}$ \\
$\mathrm{AAC}$ & $\mathrm{CTG}$ & ACT & GAA & TTC & ACC & TTT & CAG & AAC & TAC & GGC & GAC & ACC & TCC & ATC & TTG & AAA & AAG
\end{tabular}

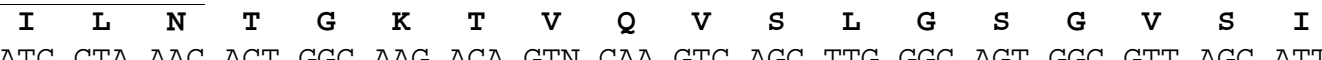
$\begin{array}{llllllllllllllllll}\mathbf{S} & \mathbf{G} & \mathbf{G} & \mathbf{D} & \mathbf{L} & \mathbf{S} & \mathbf{E} & \mathbf{A} & \mathbf{Y} & \mathbf{D} & \mathbf{S} & \mathbf{L} & \mathbf{Q} & \mathbf{F} & \mathbf{H} & \mathbf{L} & \mathbf{H} & \mathbf{W}\end{array}$ TCA GGG GGA GAT CTG TCT GAG GCA TAT GAC AGC CTG CAG TTC CAC TTG CAC TGG $\begin{array}{lllllllllllllllll}\mathbf{G} & \mathbf{K} & \mathbf{G} & \mathbf{S} & \mathbf{S} & \mathbf{I} & \mathbf{P} & \mathbf{G} & \mathbf{S} & \mathbf{D} & \mathbf{G} & \mathbf{K} & \mathbf{R} & \mathbf{Y} & \mathbf{P} & \mathbf{M} & \mathbf{E}\end{array}$ GGT AAA GGC TCC TCC ATC CCC GGC TCC GAT GGA AAG CGC TAT CCC ATG GAG gta cagtctttgttttcatgttgagctatatgttagagatttgttaacacggattatattatatacaagtattta $\begin{array}{lllllllllllll}\mathbf{L} & \mathbf{H} & \mathbf{I} & \mathbf{V} & \mathbf{N} & \mathbf{S} & \mathbf{K} & \mathbf{S} & \mathbf{T} & \mathbf{F} & \mathbf{N} & \mathbf{G}\end{array}$ attagttctctttcttattcccagTTA CAC ATT GTA AAC AGC AAG TCA ACC TTT AAT GGG $\begin{array}{llllllllllllllllll}\mathbf{N} & \mathbf{T} & \mathbf{T} & \mathbf{L} & \mathbf{A} & \mathbf{V} & \mathbf{K} & \mathbf{D} & \mathbf{S} & \mathbf{T} & \mathbf{G} & \mathbf{L} & \mathbf{A} & \mathbf{A} & \mathbf{L} & \mathbf{G} & \mathbf{F} & \mathbf{F}\end{array}$ AAC ACA ACT CTA GCT GTT AAA GAC TCT ACA GGA CTT GCT GCT CTT GGT TTC TTT I $\quad$ E

ATT GAG gtgagaggggtttttgtaatgccaatatactgattgaagttgctctaagtatcagacttatt caaagtattct tcaaaag tcaaatgctactttttttcaacactgcattatttatgatctctttaagttggt gctccactctttattattcatgccaaagccccatgaagtattttcccctccactgatacggaaacaaac

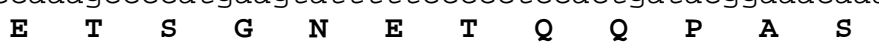

actgaagtgtgtgcacatttcagGAA ACG TCA GGC AAT GAA ACT CAG CAA CCT GCA AGC

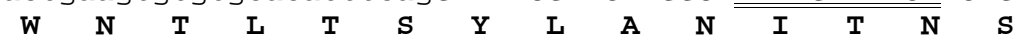

TGG AAC ACT TTG ACC TCC TAC CTG GCC AAC ATC ACA AAC AGT G gtaaggagatgctt ttgtttttttgttgaaaccgtgatctaatgttgcgaaaggaagtgccctcacagttcacatt tctaccctt

$\begin{array}{llllllllllllllllll}\mathbf{G} & \mathbf{D} & \mathbf{S} & \mathbf{V} & \mathbf{S} & \mathbf{I} & \mathbf{A} & \mathbf{P} & \mathbf{G} & \mathbf{I} & \mathbf{S} & \mathbf{L} & \mathbf{D} & \mathbf{D} & \mathbf{L} & \mathbf{L} & \mathbf{V} & \mathbf{G}\end{array}$ agGT GAC TCT GTT TCA ATT GCA CCT GGA ATT TCA TTG GAT GAC CTC CTG GTC GGG $\begin{array}{llllllllllllllllll}\mathbf{V} & \mathbf{D} & \mathbf{R} & \mathbf{T} & \mathbf{K} & \mathbf{Y} & \mathbf{Y} & \mathbf{R} & \mathbf{Y} & \mathbf{L} & \mathbf{G} & \mathbf{S} & \mathbf{L} & \mathbf{T} & \mathbf{T} & \mathbf{P} & \mathbf{Q} & \mathbf{L}\end{array}$ GTG GAT CGT ACC AAA TAT TAC CGC TAT CTT GGT TCC TTG ACC ACC CCC CAA TTG $\begin{array}{llllllllllllllllll}\mathbf{Q} & \mathbf{E} & \mathbf{A} & \mathbf{V} & \mathbf{V} & \mathbf{W} & \mathbf{T} & \mathbf{V} & \mathbf{F} & \mathbf{K} & \mathbf{D} & \mathbf{S} & \mathbf{I} & \mathbf{K} & \mathbf{V} & \mathbf{S} & \mathbf{K} & \mathbf{D}\end{array}$ CAA GAG GCT GTG GTT TGG ACT GTG TTC AAG GAT TCG ATC AAA GTC AGC AAA GAT $\mathbf{L}$

TTG gtgagatttaattttcctactgtgtaataagtaaatgctctcaacagtgcttcaccaaactaact

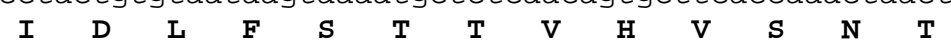
ggctcaatatcctgcctccagATT GAC CTC TTC AGC ACA ACA GTA CAC GTC TCC AAC ACC $\begin{array}{cccccccccccccccccc}\mathbf{S} & \mathbf{S} & \mathbf{P} & \mathbf{L} & \mathbf{M} & \mathbf{T} & \mathbf{N} & \mathbf{V} & \mathbf{F} & \mathbf{R} & \mathbf{N} & \mathbf{V} & \mathbf{Q} & \mathbf{P} & \mathbf{A} & \mathbf{Q} & \overline{\mathbf{P}} & \mathbf{V} \\ \text { TCG } & \text { TCA } & \text { CCT } & \text { TTG } & \text { ATG } & \text { ACC } & \text { AAT } & \text { GTC } & \text { TTC } & \text { AGA } & \text { AAC } & \text { GTC } & \text { CAG } & \text { CCA } & \text { GCA } & \text { CAA } & \text { CCA } & \text { GTC }\end{array}$

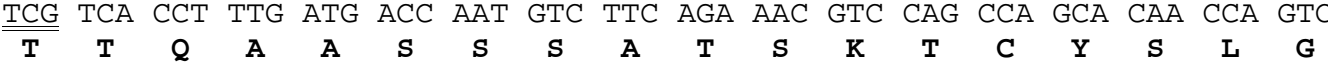
ACA ACA CAG GCT GCC AGC AGT AGC GCT ACC TCC AAA ACC TGT TAC TCT CTG GGG L $\quad \begin{array}{llllllllllll} & \mathbf{A} & \mathrm{L} & \mathbf{S} & \mathrm{L} & \mathbf{A} & \mathbf{L} & \mathbf{G} & \mathbf{R} & \mathbf{S} & \text { * }\end{array}$ TTG ATG GCA CTG AGC CTG GCT CTG GGG AGG AGT TAG ggccaatgaagaatgggggggga gaattattgtggtggtttggcaacttatggtgctgctggtaaacctgttagtatacacctatctcactatt atcctctt tcaatgtgatttgtctgact taaacctccaaattgttagggcgcagttttgcttggatttgact aacgccgcaagaacttttgttgtgttccagtctagctctctatatatttgtcataatgaattgt tcacaaac at taaatgtgataatggctatagttgtccatattgcttccaggagtatgaaaagctataaagaatttatcaa tctgattttaatctgttgctcactatatttatgttaaacattgtgcacaagaatgaacatgtt $\overline{t \text { tgcagaat }}$ gactggttcaggcacagctaatgact gcgcttgagctgtcaaagctacatttaggagcctgaggcaggaatg cacttgcactaagtttacagga 
Fig. 2. Semi-quantitative RT-PCR determination of expression levels of carbonic anhydrase in gills (black) and intestine (white) of sea bass ( $n=5$ for each condition). Results are presented as the ratio OD CA / OD 28S. The four conditions tested are sea bass experimentaly acclimated to seawater (SW) or fresh water (FW) and wild sea bass (Mediterranean Sea [Sea] and Ingril lagoon [Lag]).

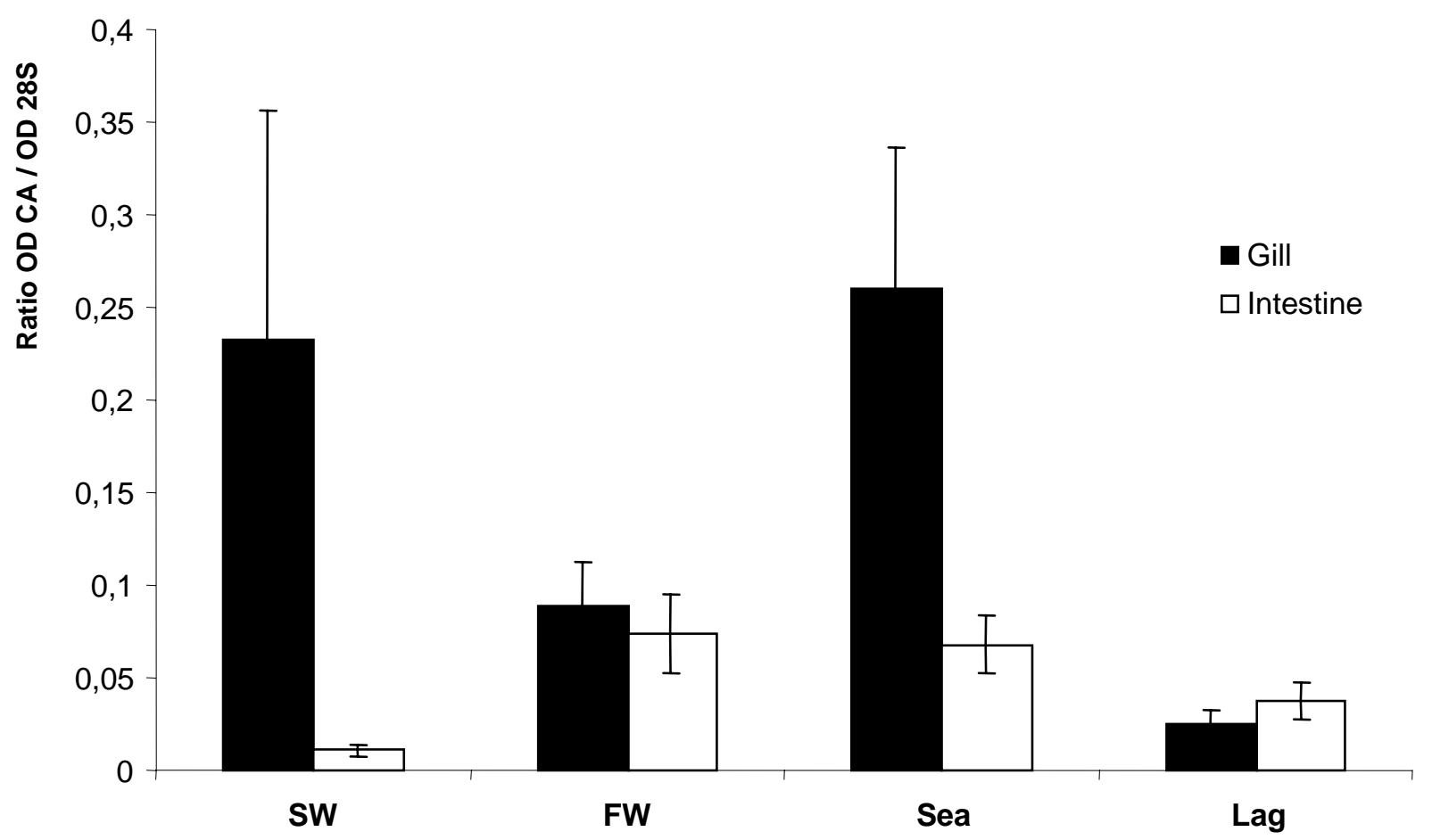


Fig. 3. Semi-quantitative RT-PCR determination of expression levels of $\mathrm{Na}^{+} / \mathrm{K}^{+}$-ATPase, angiotensinconverting enzyme, claudin-3, nephrosin and secretagogin in gill (A) and intestine (B) of sea bass ( $n=5$ for each condition). Results are presented as the ratio OD gene / OD 28S. The animals were collected in Mediterranean Sea [Sea] (grey) and Ingril Lagoon [Lag] (white). Significant values at 5\% are shown by an asterisk $(*)$.

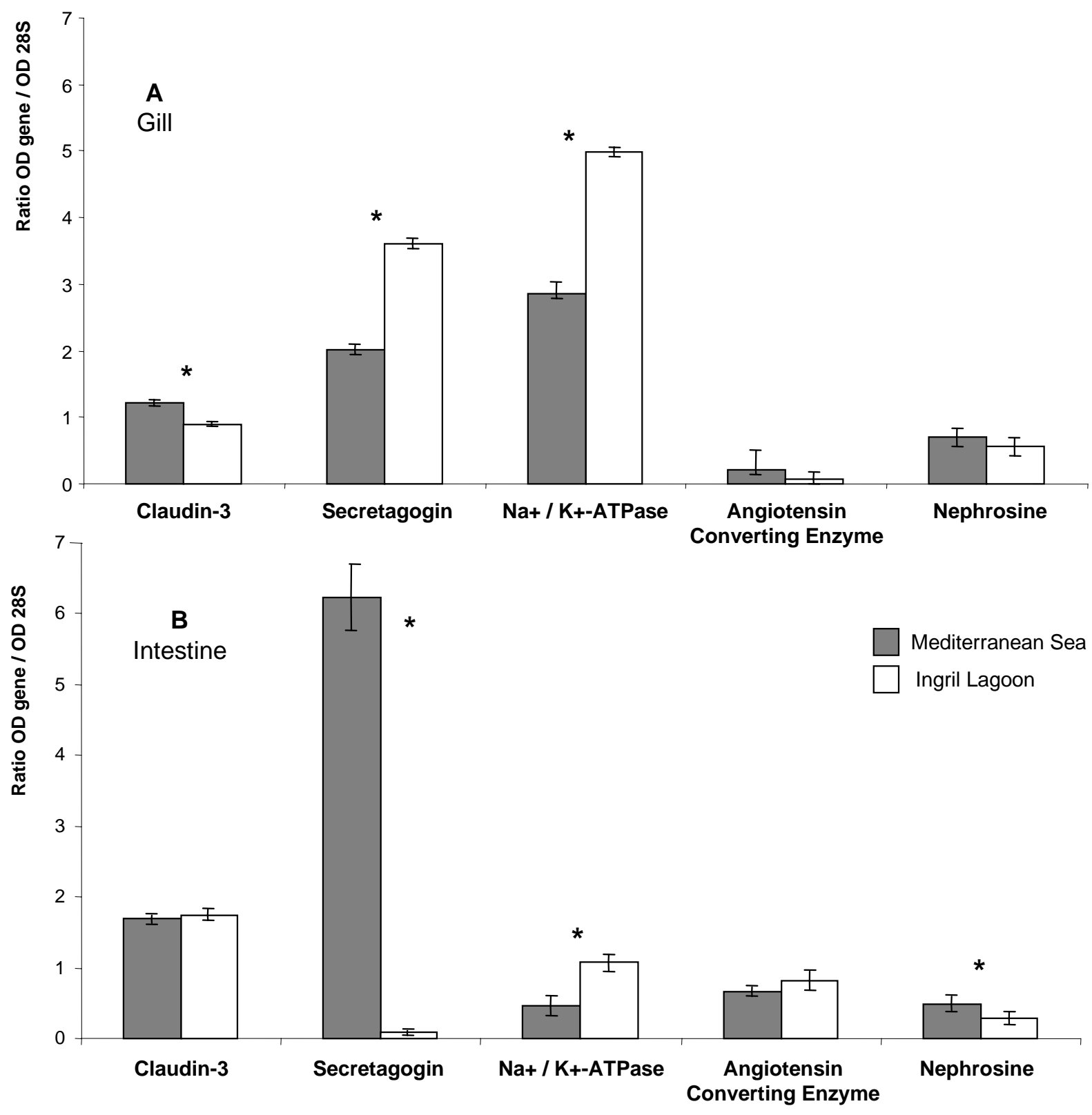

